\title{
Halal labeling effect on muslim consumers attitude and behavior
}

\author{
Syaifuddin Fahmi \\ Sekolah Tinggi Ilmu Ekonomi Kertanegara Malang \\ INDONESIA \\ Syaifuddin_fahmi@stiekma.ac.id
}

\begin{abstract}
The Halal food market in Indonesia has a big potential where $88 \%$ of the population is Muslim. The number of Islamic population in Indonesia according to the Central Bureau of Statistics (BPS) in 2010 reached 207.1 million people, where the largest population is on the island of Java. Even Thombson Reuters article (2015) showed that Indonesia got first ranks "Top Muslim consumer food expenditure markets". Halal logo Majelis Ulama Indonesia (MUI) is a certification of halal product listed in food products, and non-food products. Halal logo MUI has global access, where export and import products traded in Indonesia should have it. Muslims in Indonesia are very concerned about halal issues, because in Islamic religious are prohibited to consume haram products, including foods that are not hygienic and contaminated with haram materials. This research uses quantitative approach through survey method and multiple regression analysis in use to measure the influence of independent variable to dependent variable. Theory of Reasoned Action (TRA) is used to construct hypothetical models. A total of 152 responses were received from 200 questionnaires distributed, which gave a response rate of 76 percent. Respondents were taken from three different places; Minimarket, Fast Food Restaurant, and Supermarket in Malang, East Java, Indonesia. The result of the analysis stated that attitude toward halal labeling and subjective norm have positive and significant influence on the variable of intention with significance level less than 0.001 .
\end{abstract}

Keywords-Attitude, halal label, TRA Theory, consumer behavior

\section{I.Introduction}

Halal is the main requirement of food, medicines, cosmetics and other consumer goods that can be eaten, used, or applied directly to the body by Muslims [1]. Products consumed cannot contain the types of materials that are considered Haram - the opposite of Halal - especially alcohol, pork or pork processed products, any type of animal blood, dead animals without slaughter, and the animals are slaughtered in the name of other than Allah [2]. In addition to getting the Halal certificate, you also need to register your product under BPOM to prove that your product is beneficial for consumers and does not contain hazardous materials [3]. All the products have obtained Halal certificate will have the right to include the Halal logo on the product packaging [4]. Halal Logo Indonesia show consumers which products that can be consumed by Muslims and who can not. Food or cosmetic products are sold without a logo can be considered as Halal or Haram, which means that Islam as much as $88 \%$ of the total population in Indonesia [5], will tend to avoid such products. Thombson Reuters article (2015) showed that Indonesia got first ranks "Top Muslim consumer food expenditure markets".

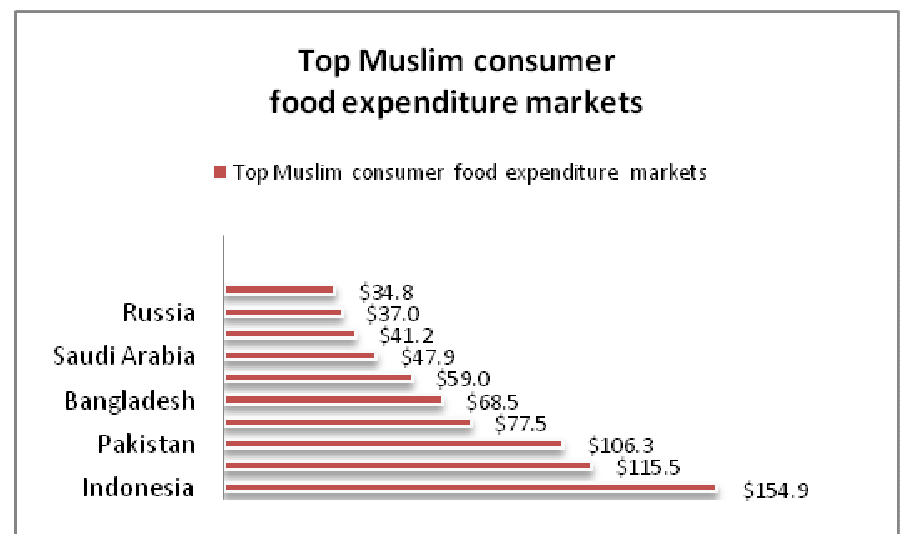

figure 1. Muslim consumer food expenditure markets[6]

Halal Certificate issued by the Indonesian Ulema Council (MUI / Majelis Ulama Indonesia) after certain tests and analyzes carried out by the Institute for Food, Drugs and Cosmetics Indonesian Ulema Council (MUI LPPOM) to see if the product meets the requirements [4]. The laws affecting Muslim consumption behavior stem from the holy Qur'an that explained about what is permissible (halal) and what is not allowed (haram) for muslim (Mukhtar \& Butt, 2012). Halal certification is very commonly needed in the food, beverage, hospitality and restaurant industries regarding the importance of knowledge about halal restrictions for Islamic consumers [7]. In some studies found also the implementation of halal principles in the supply chain, namely by avoiding direct contact with the Haram object, overcoming the risk of contamination and ensure it is in accordance with Muslim consumer perceptions [8]. Even other religious or non-Muslim consumers understand the importance of halal principles that also address health issues, food safety and environmentally friendly ways of production [9]. Consumer awareness of Muslims in Indonesia in obtaining products that must comply with Islamic sharia is very high especially in the food industry [10]. The increased religious awareness of Muslim consumers will encourage producers or industries to provide products labeled halal as selling points or branding in convincing consumers[11]. Thus, halal label stamped on the product is one of the factors that attract Muslim consumers in deciding the purchase. 


\section{LITERATURE REVIEW}

\section{A. Halal Concept}

Islam teaches Muslims to consume the Halal product. Based on Islamic law there are three categories of products for Muslims i.e. halal, haram, and mushbooh. Halal in Arabic means Permitted, usable, and lawful. The opposite of halal is haram which means not allowed, can not be used, and illegally according to law. Whereas mushbooh (syubha, Shubhah, and mashbuh) means black and white, still questionable, and doubt is therefore best for Muslims to avoid it [1].

Basically, all clean and well processed foods are allowed to be consumed by Muslims, except for the following categories including products derived from them or contaminated with them [4]

1. Dead animals

2. Blood flowing or freezing

3. Pigs (all variants) including all the products

4. An animal is slaughtered without uttering the name of Allah on it

5. Animal is slaughtered while uttering a name other than Allah.

6. Animals are killed in a way that prevents their blood drained from their bodies

7. All kinds of alcoholic beverages and narcotics

8. Animal carnivores with fangs, such as lions, dogs, wolves or tigers

9. Birds with sharp claws (birds of prey) such as eagles, hawks, owls or vultures

10. Animals that live on land and water such as frogs or snakes

Halal Sertification. Halal Certificate is a written fatwa of the Indonesian Ulama Council (MUI) which states the halalness of a product in accordance with Islamic shari'ah. Halal Certificate is a requirement to get permission to include Halal label on product packaging from authorized government institution [1] Halal certification issued by MUI on food products, medicines, cosmetics and other products is done to provide certainty of halal status, so as to provide certainty and security for consumers in consuming it. [2]. The Halal Product Process (PPH) is a series of activities to ensure Halal Product includes the provision of materials, processing, storage, packaging, distribution, sale and presentation of the Product [1]. To obtain halal label from MUI, the business actor shall submit a request for Halal Certificate in writing to the Halal Product Guarantee Organization (BPJPH), documents needed in the form of business actor data, product name and type, product list and materials used and description related to product processing [4]. Estimated revenues from Halal Certified Food and Beverage products \$415 Billion in 2015 [6]
Halal Marketing Concept. The Islamic ethical framework has a level with several approaches, halal certification is proposed to facilitate the application of Islamic business ethics in a relative context. Halal business practices provide harmonization of global standards and governance structures, and integrate ethical responsibilities and issues in the form of standards to be followed [12]. Customers are willing to spend a lot of effort and money to buy Halal food [13]. The majority of British Muslims do not trust large supermarkets when buying halal meat. They will only trust a Muslim who sells halal products in their local stores. Most respondents do not know that supermarkets in their area sell halal meat [14].

Malaysia as a Muslim majority country is conducting studies related to halal products, with some findings such as the desire of consumers to choose kosher cosmetics and the intention to choose halal food products among Malaysian consumers. [11]. Malaysian consumers have more positive attitudes and intentions towards halal food products than Halal cosmetics products [11] .The consumer perception is influenced by the level of knowledge and religiosity [15]. Good corporate image will affect consumer confidence [16]. So that a good corporate image will stimulate positive and profitable preference from consumers in their decision making In addition, good corporate image will also affect consumer confidence [16]. Halal perceptions are intermediate variables that intervene in the tendency to make purchasing decisions [17]. Socialization and information have led to a lack of knowledge and awareness about the concept of halal [11]. Some consumer have a different perception of Halal food products. It also shows that consumer perceptions and their level of knowledge and religiosity are different [15]. On the other hand the role of Muslim families to educate their young family members about halal food should be improved [18].

\section{B. Theoretical framework}

Theory of Reasoned Action (TRA). The theory is used to investigate the role of attitudes toward consumer intentions to purchase products [19]. This theory connects beliefs, attitudes, intentions and behaviors. Intention is the best predictor of behavior, meaning that if you want to know what someone will do, the best way is to know the intention of the person. However, one can make judgments based on completely different reasons, not always based on intention. [20]. The theory said that attitudes affect behavior through a careful and reasoned decision-making process and limited impact only on three things; first, the behavior is not much determined by the general attitude but by a specific attitude toward something. Second, behavior is affected not only by attitude but also by the subjective norms (beliefs) we are about what others want us to do. Third, attitude towards a shared behavior of subjective norms constitutes an intention or intention behaves in a certain way [21].

Theory of Reasoned Action is the right model in predicting the intention of choosing a halal product [21]. Where positive attitudes toward the consumption of Halal products, personal beliefs and perceived control over consume are able to predict the intention to consume halal products among Muslims. [22]. Factors of subjective attitudes and norms have a strong influence on the intention to buy halal 
food products [23]. Subjective norms are also positively related to attitudes [24]. Other studies suggest interest to behave is influenced by attitudes, perceived behavior control, subjective norms and halal imagery. Muslim consumers develop a good attitude towards the store that features the image of Halal, and are happy to know that every item available in this store is a confirmed Halal product [25].

The theory of attitude suggests that there are a positive relationship between the attitude and intentions of choosing kosher cosmetic products.Considerations of Halal cosmetics and attitudes toward halal food products are different [26]. Individual perceptions of Halal logic are influenced by their specific goals or business interests -an organization [27]. Other findings suggest that most consumers earn perceps Halal from product marketing information, personal and societal and from Halal certification label. Customers are also influenced by Halal and Branding Product Marketing practices. [13].

Attitude. Attitudes toward behavior defined as positive or negative individual feelings about performing a behavior. This is determined through an assessment of one's beliefs about the consequences arising from the behavior and evaluation of the consequences of consequences [20]. Attitudes toward behavior (attitude toward behavior) is formed by: 1). Behavioral Belief (belief behavior), namely the belief that behavior will result in an outcome or belief in the consequences of doing certain behaviors. 2). Outcomes Evaluation / Evaluation of the Consequency (evaluation of consequences), ie evaluation of an outcome or evaluation of the consequences of behavioral beliefs [19]. Some researchers assume that attitudes have three major components: cognition, affect and behavior [28].

Subjective Norm. Fishbein and Ajzen define subjective norms as individual perceptions of whether people are important to individuals thinking behavior should be done. The contribution of the opinions of each given reference is weighted with the motivation that an individual must comply with the wishes of that reference [20]. The subjective norms are formed by: 1). Normative Belief, ie belief in others (reference group or reference) that they think the subject should or does not engage in a normative behavior or belief about the other person's (reference group) expectations of what should be done. 2). Motivation to Comply (motivation to obey), which is motivation in line with normative beliefs or motivations that are in line with the person who became the reference group [19]. According to Ajzen, subjective norm is the extent to which a person has the motivation to follow the person's view of his or her normative belief. If the individual feels it is his / her personal right to decide what he or she is going to do, not determined by others around him, then he / she will ignore people's view of the behavior they will do.

Purchase Intention. Fisbein and Ajzen describe buying intentions as a person's situation before performing an action, which can be the basis for predicting the behavior or action [19]. Buying intent or customer purchase priority begins by collecting product information based on personal experience and the surrounding environment. After getting the information up to a certain level, the customer arrives at the process of estimating and evaluating, then making a purchase decision after comparing and making consideration. This variable was measured by using 3 indicators : 1) Choosing the halal products, 2) The desire to buy the halal products, 3) recommending to the friends and relatives. One of the causes of purchase intentions is the subjective norm which is a function of the perceived expectations of the individual in which one or more people around him (eg, relatives, peers) agree on a particular behavior and motivate the individual to obey them[20].

Objective of the study. This study aims to determine attitudes of Muslim consumers in Malang (Indonesia) against products with halal label. Furthermore, the attitudes formed will affect the consumer's intention to choose halal product, and can be used as a basis in the decision to purchase halal products.

\section{METHODOLOGY}

The data for this study are obtained through structured questionnaires and distributed to respondents (muslim consumers), questionnaire consists of four parts (demographic, attitudes toward halal label, subjective norms, and intentions). The survey was conducted in Malang, Indonesia in March 2017 at selected locations (i.e. minimarkets, fast food restaurants, and supermarket). The data collection process uses the convenience sampling method and is based on a selfadministered principle [29]. Convinience sampling is the sampling procedure of obtaining those people or units that are most conveniently available [30]. Before the questionnaire was given, respondents were asked whether they would participate or not in the study, to fill out the questionnaire. If they agree, the researcher will submit the questionnaire to be answered and collected after completion. A total of 152 responses were received from a total of 200 questionnaires distributed, which gave a response rate of 76 percent.

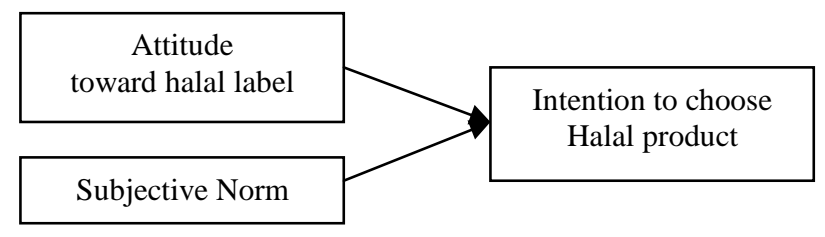

Figure 2. A schematic diagram of the conceptual framework

\section{A. Method of analysis}

Characteristics of respondents based on the results of descriptive analysis showed that, based on the gender of male respondents have a higher number (65.1 percent), and female (34.9 percent). The majority of educational data have a high educational background, from the University's educational background (43.4 percent), and high school respondents (40.2 percent), while (15.8 percent) are respondents with primary and secondary education. Based on age data, the majority of respondents are in the age category $30-44$ years (46.1 percent) and 18-29 years old (30.9 percent), 45-59 years old is the least (23 percent). In all respondents, some were taken from Mini Market location (37.5 percent), Super Market location (32.9 percent) and Fast Food Restaurant (29.6 percent). 
Table.1 Demographic Profile

\begin{tabular}{ccc}
\hline Variable & $f$ & Percentage \\
\hline Age group & & 30,9 \\
$18-29$ & 47 & 46,1 \\
$30-44$ & 70 & 23,0 \\
$45-59$ & 35 & \\
Education group & & 15,8 \\
Basic & 24 & 40,8 \\
High school & 62 & 43,4 \\
University & 66 & \\
Gender group & & 65,1 \\
female & 99 & 34,9 \\
male & 53 & 37,5 \\
Location group & & 29,6 \\
Mini Market & 57 & 32,9 \\
Fast Food Restaurant & 45 & \\
Super Market & 50 & \\
\hline
\end{tabular}

\section{B. Data analysis}

The questionnaire items were based on selected variable research indicators [20]. Respondents were asked to rate their agreement with the statement given by the researcher, using the likert scale of seven points, where "Strongly Disagree" (1) and to "Strongly agree" (7). The questionnaire is written in Indonesian language. Respondents' demographic data were processed using descriptive analysis and regression analysis was used to analyze the scaled data.

\section{Research Hypothesis}

The hypothesis is a temporary answer to the real problem which is the truth must be tested. Some variables used are a latent variable, where the variable cannot be observed directly but can be measured through indicators[30]. Based on the review of existing literature and research objectives, then the author make the hypothesis as follows:.

H1. There is a significant and positive relationship between attitude toward halal label and intention to choose halal products.[20]

$\mathrm{H} 2$. There is a significant and positive relationship between subjective norm and intentions to choose halal products.[19]

\section{IV.RESULT AND DISCUSSION}

\section{A. Result}

Internal reliability. The item is verified by calculating the Cronbach alpha value [31]. Nunnally recommends that alpha more than 0.6 be sufficient for the initial stages of the study. The alpha Cronbach estimated for attitude is 0.731, the subjective norm is 0.743 , and the behavioral intention scale is 0.8090. Because Cronbach's alpha in this study is much higher than 0.6 , it is considered to have adequate reliability.

Table II. Reliability coefficient

\begin{tabular}{ccccc}
\hline Variabel & Item & Cronbach's & Mean & SD \\
\hline Attitude & 2 & 0,758 & 6,441 & 0,8910 \\
Subjective Norm & 2 & 0,743 & 6,471 & 0,8932 \\
$\begin{array}{c}\text { Intention to choose } \\
\text { Halal } \text { Product }\end{array}$ & 3 & 0,809 & 6,614 & 1,2401 \\
\hline
\end{tabular}

Mean and deviation. The mean value indicates the average respondent's answer for all items asked in the questionnaire. Where the research results show that the average value for attitude variable is $(6,441)$, for subjective norm variable has mean value $(6,471)$ and for variable of intention to choose halal product its mean value is $(6,614)$. Overall the average score of respondents 'answers is $(6,509)$, meaning that all respondents' "strongly agree" that the halal label has an influence on attitudes, and the intention to choose food products.

Normality and multicolinearity. In the data normality test and multicolinearity of this study involved a sample (152 respondents). Two main methods used to know the existence of multikolinearitas between independent variables in this study. This methodology involves the calculation of both tolerance test and inflation variable (VIF)[29]. The results of this analysis are presented in Table III, from the multicollinearity test data found that none of the tolerance levels are less than or equal to 0.01; And all VIF values are far below 10. Thus, the measure chosen to assess the independent variables in this study did not reach a level that indicated multicolinearity.

Table III. Test of collinearity

\begin{tabular}{ccc}
\hline Variabel & Tolerance & VIF \\
\hline Attitude & 0,803 & 1,245 \\
Subjective Norm & 0,803 & 1,245
\end{tabular}

Regression. Table IV presents the results of multiple regression analysis, the results used to evaluate the strength of the proposed relationship. Two hypotheses are formulated and all variables are maintained after testing the reliability. Individual hypotheses were tested using multiple regression prediction models following the guidelines established [29]. Intention of buying halal food as a dependent variable. The results obtained, as shown in Table IV, reveal that $\mathrm{H} 1$ and $\mathrm{H} 2$, found significant in the prediction model, $(p-$ value $=0,000<$ 0,001). 
Table IV. Regression results

\begin{tabular}{cccc}
\hline variabel & $\beta$ & $t-$ value & $p$-value \\
\hline Constant & 2,131 & 5,153 & $0,000^{* * *}$ \\
Attitude & 0,411 & 6,973 & $0,000^{* *}$ \\
Subjective Norm & 0,280 & 4,648 & $0,000^{* *}$ \\
\hline
\end{tabular}

Attitude variable is positively related to the intention to choose halal products $(\beta=0.411, p<0,001)$, and Subjective norm was also found to be positively related to intention to choose halal product $(\beta=0.411, p<0,001)$. Thus, $\mathrm{H} 1$ and $\mathrm{H} 2$ of this study are fully supported. Table IV shows that attitude is the most significant predictor of intention to choose halal products.

Table V. Model Summary of Regression

Model Summary

\begin{tabular}{ccccc}
\hline Model & $\mathrm{R}$ & $\mathrm{R}$ Square & $\begin{array}{c}\text { Adjusted R } \\
\text { Square }\end{array}$ & $\begin{array}{c}\text { Std. Error of the } \\
\text { Estimate }\end{array}$ \\
\hline 1 & $0,673^{\mathrm{a}}$ & 0,453 & 0,445 & 0,294
\end{tabular}

a. Predictors: (Constant), subjective norm, attitude

From the summary model can be obtained the value of $\mathrm{R}$ square $=0.453$, and the value adjusted $R$ squeare $=0.445$. This indicates that the two dependent variables of attitude and subjective norm can explain the dependent variable of intention to choose halal product by $45 \%$ while the remaining $65 \%$ is explained by other variables.

\section{B. Discussion}

The results indicated that theory of reasoned action (TRA) is a valid model in predicting intention to choose Halal products[21]. There are positive influence that signifikan of attitude variable to intention to choose halal product. This study is in accordance with the research of Mukhtar, Arshia Butt, Muhammad Mohsin [21], and Lada, Suddin Tanakinjal, Geoffrey Harvey Amin, Hanudin [24], the results of research on Muslims in pakistan and Muslim consumers in Malaysia found significant influence between attitudes Against the intention to behave in the purchase of halal products. The similarity of these results shows that Muslims in the world have similarities in understanding the principles of halal (allowed to be consumed) or haram (not allowed to be consumed). Muslims realize that this attitude arises from the understanding of the holy Qur'an teaching and believes it will bring goodness.

Furthermore, these results complement findings of previous studies that also measure the influence of attitudes toward behavioral intention, Butt, Muhammad Mohsin Muhamamd Mohsin; Muhammad Aftab, Muhammad [32] This study investigates the level of understanding of Halal principles among non-Muslims in Malaysia. The results show the same thing that the 800 respondents paid special attention and understood the halal principles applied in Malaysia. Even they think that halal certification provides its own benefits for them. Another study that also obtained similar results was Khalek, Aiedah Abdul [18], who examined Young consumers' attitude toward halal food outlets and JAKIM's halal certification in Malaysia. Or Awan's research, Hayat Muhammad Siddiquei, Ahmad Nabeel Haider, Zeeshan, [13], who investigated Factors affecting Halal purchase intentionevidence from Pakistan's Halal food sector. The results of the study support the TRA theory developed by Ajzen, Icek Fishbein, Martin and Theory of Planned Behavior (TPB) which is the development of the TRA theory[19].

Other researches include Potluri, Rajasekhara Mouly Ansari, Rizwana Khan, Saqib Rasool Dasaraju, Srinivasa Rao [33] who studied Indian Muslims' attitude and consciousness towards halal, Syed Shah Alam Nazura Mohamed Sayuti [23] who examined Applying the Theory of Planned Behavior (TPB) in halal food purchasing. From many research results that mention the importance of halal certification for Muslims, it is expected the food producers begin to consider to register their products to obtain halal label so as to provide a sense of security and confidence to muslim consumers. The government also has a great responsibility to make regulations of local and imported products by incorporating the provisions of Islamic law.

\section{Limitation and future research}

This research was conducted in Malang city, east java, with limited number of respondents. The results of this study only provide a picture of consumer behavior on the object under study and cannot be generalized to a larger population in the region of Indonesia or in other countries. Future research will be expected to examine a wider scope involving cooperation of several regions or some countries. Research on halal products still requires further study and development because this issue is still little studied, especially in Indonesia. The results of research on halal products will give benefit to muslim consumers and also provide many benefits for producers, especially those who take the segment of Islamic countries like Indonesia.

\section{Conclusion}

The results indicate that attitude toward halal label and subjective norms are important antecedents of Indonesian Muslims intention to choose Halal products. Therefore, marketing researchers and producers are expected to conduct an in-depth study related to halal issues in the predominantly Muslim nation of Indonesia, or to Islamic consumers around the world. So that the resulting product meets the requirements for consumption or in use by Muslims.

\section{References}

[1] LPPOM MUI, "Prosedur, persyaratan dan kebijakan Sertifikat Halal MUI, Indonesia,” 2017. [Online]. Available:

http://www.halalmui.org/mui14/index.php/main/go_to_s ection/55/1360/page/1. [Accessed: 01-Apr-2017].

[2] MUI, "Halal Certification, 'Majelis Ulama Indonesia,", 2017. [Online]. Available: http://mui.or.id/id/category/produk/sertifikasi-halal/. [Accessed: 05-Apr-2017]. 
[3] T. Muhammad, "Implementasi Undang-Undang Nomor 33 tahun 2014 tentang jaminan produk halal, Indonesia," 2016. [Online]. Available:

http://bimasislam.kemenag.go.id. [Accessed: 25-Mar2017].

[4] Kemenag, "Undang-undang republik indonesia nomor 33 , tentang jaminan produk halal, 'Kementrian Agama,"” 2014. [Online]. Available: http://simbi.kemenag.go.id/halal/assets/collections/newsl etter/files/55642ca917160.pdf. [Accessed: 28-Mar2017].

[5] BPS, "Penduduk menurut wilayah dan agama yang dianut di Indonesia," 2010. [Online]. Available: http://sp2010.bps.go.id/index.php/site/tabel?tid=321. [Accessed: 04-Mar-2017].

[6] T. Reuters, State of The Global Islamic Economy Report 2016/17. Thomson Reuters : The Answer Company, 2017.

[7] S. Zannierah Syed Marzuki, C. M. Hall, and P. W. Ballantine, "Restaurant managers' perspectives on halal certification," J. Islam. Mark., vol. 3, no. 1, pp. 47-58, 2012.

[8] M. Tieman, "The application of Halal in supply chain management: in-depth interviews," J. Islam. Mark., vol. 2, no. 2, pp. 186-195, 2011.

[9] G. Rezai, Z. Mohamed, and M. N. Shamsudin, "NonMuslim consumers' understanding of Halal principles in Malaysia," J. Islam. Mark., vol. 3, no. 1, pp. 35-46, 2012.

[10] C. Ratanamaneichat and S. Rakkarn, "Quality Assurance Development of Halal Food Products for Export to Indonesia," Procedia - Soc. Behav. Sci., vol. 88, pp. 134-141, 2013.

[11] S. Prabowo, A. Abd Rahman, S. Ab Rahman, and A. A Samah, "Revealing factors hindering halal certification in East Kalimantan Indonesia," J. Islam. Mark., vol. 6, no. 2, pp. 268-291, 2015.

[12] M. Ismaeel and K. Blaim, "Toward applied Islamic business ethics: responsible halal business," J. Manag. Dev., vol. 31, no. 10, pp. 1090-1100, 2012.

[13] H. M. Awan, A. N. Siddiquei, and Z. Haider, "Management Research Review Factors affecting Halal purchase intention -evidence from Pakistan's Halal food sector," Manag. Res. Rev. Int. J. Commer. Manag., vol. 38, no. 1, pp. 8-20, 2015.

[14] A. Ahmed, "Marketing of halal meat in the United Kingdom: Supermarkets versus local shops," Br. Food J., vol. 110, no. 7, pp. 655-670, 2008.

[15] M. Said, F. Hassan, R. Musa, and N. A. Rahman, "Assessing Consumers' Perception, Knowledge and Religiosity on Malaysia's Halal Food Products," Procedia - Soc. Behav. Sci., vol. 130, pp. 120-128, 2014.
[16] N. M. Mohtar, N. A. Amirnordin, and H. Haron, "Ayamas Food Corporation Sdn. Bhd: A Study on the Factors of Consumer Behaviour towards Halal Product Selection," Procedia - Soc. Behav. Sci., vol. 121, no. September 2012, pp. 166-185, 2014.

[17] Suraiya Ishak et al., "A Study on The Mediating Role of Halal Perception: Determinants and Consequence Reflections," J. Islam. Mark., vol. 7, no. 3, 2016.

[18] A. A. Khalek, "Young Consumers' Attitude towards Halal Food Outlets and JAKIM's Halal Certification in Malaysia," Procedia - Soc. Behav. Sci., vol. 121, no. September 2012, pp. 26-34, 2014.

[19] I. Ajzen and M. Fishbein, Predicting and Changing Behavior, The Reasoned Action Approach. Psichology Press, New York, 2005.

[20] I. Ajzen and M. Fishbein, Understanding Attitudes and Predicting Social Behavior. Prentice Hall, Inc., Upper Saddle River, NJ., 1980.

[21] A. Mukhtar and M. M. Butt, "Intention to choose Halal products: the role of religiosity," J. Islam. Mark., vol. 3, no. 2, pp. 108-120, 2012.

[22] A. Ali, G. Xiaoling, M. Sherwani, and A. Ali, "Factors affecting Halal meat purchase intention: Evidence from international Muslim students in China," Br. Food J., vol. 119, no. 3, 2017.

[23] Syed Shah Alam and Nazura Mohamed Sayuti, "Applying the Theory of Planned Behavior (TPB) in halal food purchasing," Int. J. Commer. Manag., vol. 21, no. 1, pp. 8-20, 2011.

[24] S. Lada, G. H. Tanakinjal, and H. Amin, "Predicting intention to choose $<\mathrm{IT}>$ halal $</ \mathrm{IT}>$ products using theory of reasoned action," Int. J. Islam. Middle East. Financ. Manag., vol. 2, no. 1, pp. 66-76, 2009.

[25] N. Mohd, S. Abang, and S. Abang, "Does Halal image strengthen consumer intention to patronize Halal stores?: Some insights from Malaysia," J. Islam. Mark., vol. 7, no. 1, pp. 120-132, 2016.

[26] A. Abd-Rahman, E. Asrarhaghighi, and S. Ab Rahman, "Consumers and Halal cosmetic products- knowledge, religiosity, attitude and intention," J. Islam. Mark., vol. 6, no. 1, pp. 148-163, 2015.

[27] D. Poniman, S. Purchase, and S. Joanne, "Traceability systems in the Western Australia halal food supply chain," Asia Pacific J. Mark. Logist., vol. 27, no. 2, pp. 324-348, 2015.

[28] S. P. Robbins and T. A. Judge, Organizational Behavior, 15th ed. Pearson, Prentice Hall, USA., 2013.

[29] R. L. Hair, Jr., J. F., Black, W. C., Babin, B. J., Anderson, R. E., \& Tatham, Multivariate Data Analysis, 6th ed. Prentice Hall, Inc., Upper Saddle River, NJ., 2006.

[30] W. G. Zikmund, B. J. Babin, J. C. Carr, and M. Griffin, Business Research Methods, 9th ed. South-Western, 
USA., 2013.

[31] J. C. Nunnally, Psychometric theory, 2nd ed. McGrawHill, New York, 1978.

[32] M. M. M. M. M. A. Butt and M. Aftab, "Incorporating attitude towards Halal banking in an integrated service quality, satisfaction, trust and loyalty model in online Islamic banking context," Int. J. Bank Mark., vol. 31, no. 1, pp. 6-23, 2013. 